Supplement of Biogeosciences, 17, 245-263, 2020

https://doi.org/10.5194/bg-17-245-2020-supplement

(C) Author(s) 2020. This work is distributed under

the Creative Commons Attribution 4.0 License.

(c) (1)

Supplement of

\title{
Coccolithophore biodiversity controls carbonate export in the Southern Ocean
}

Andrés S. Rigual Hernández et al.

Correspondence to: Andrés S. Rigual Hernández (arigual@usal.es)

The copyright of individual parts of the supplement might differ from the CC BY 4.0 License. 

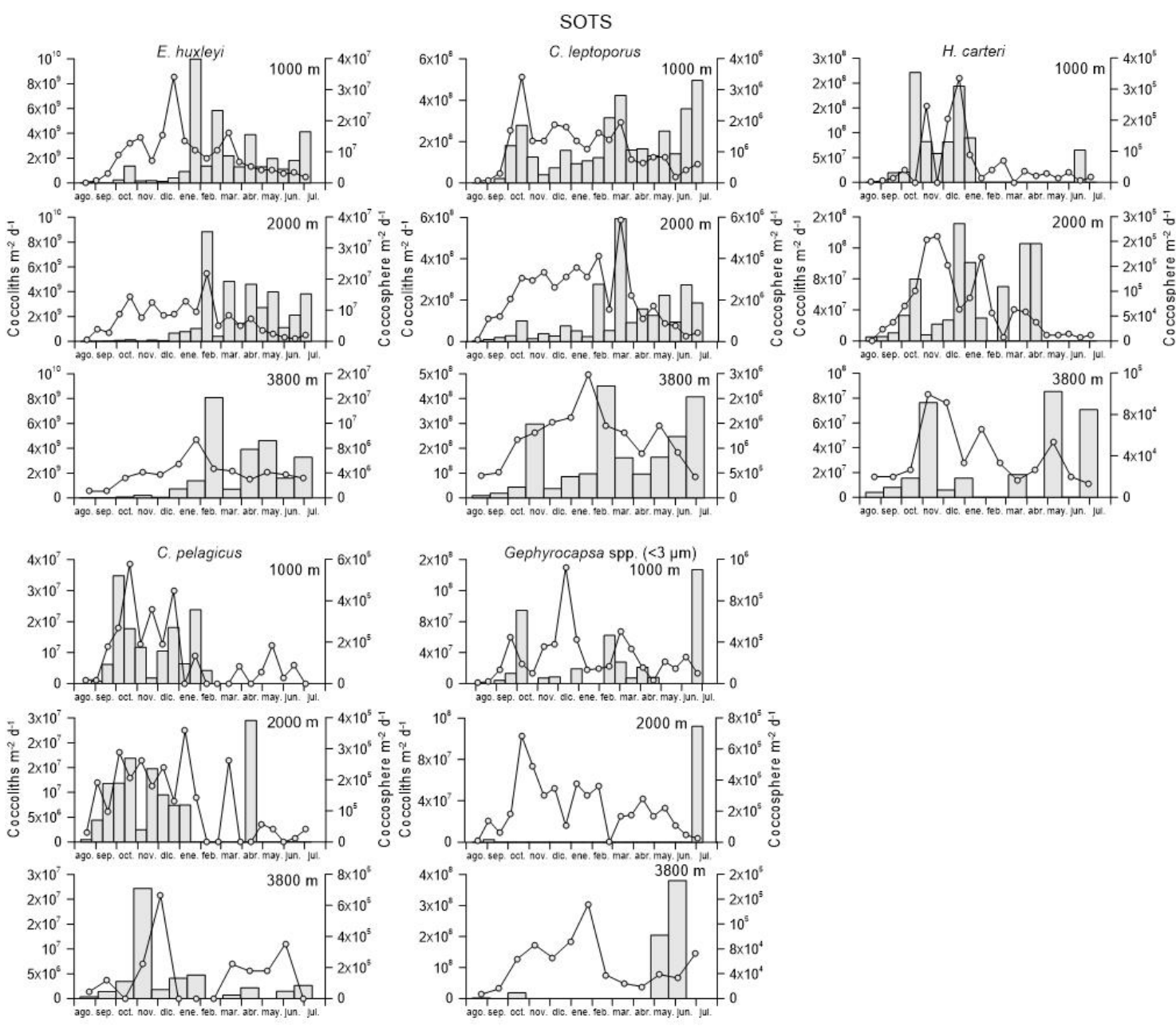

a
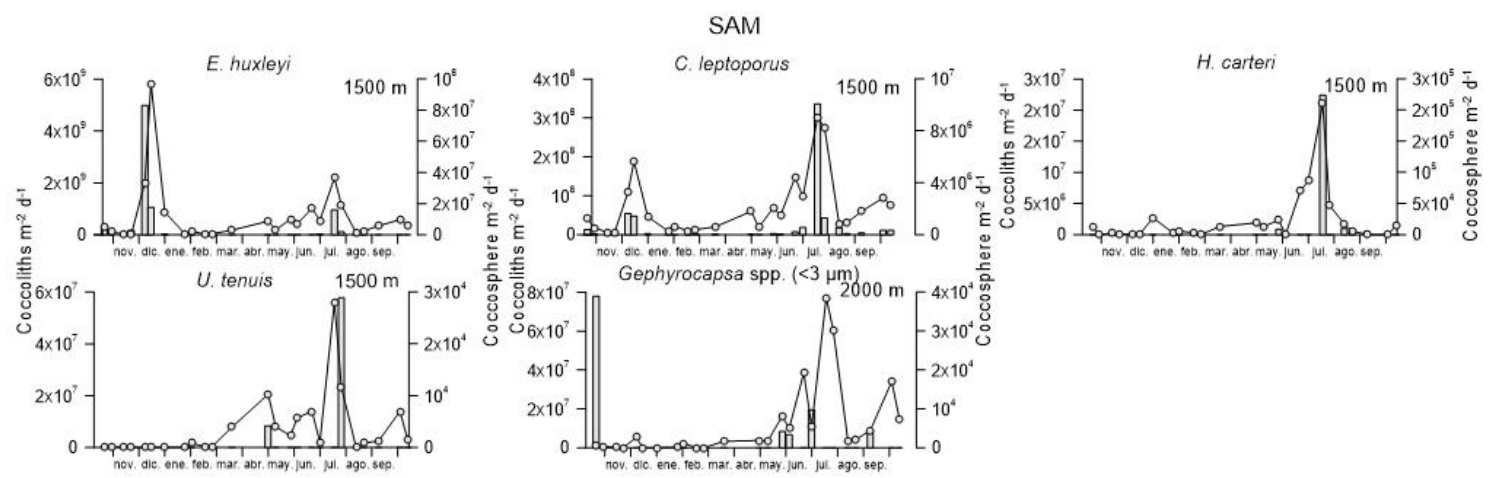

b

Supplement Figure 1. Seasonal variation of coccolith and coccosphere fluxes of the main coccolithophore species collected by the SOTS sediment traps (at 1000, 2000 and $3800 \mathrm{~m}$ depth) between August 2011 to July 2012 and the SAM sediment trap (1500 m) between November 2009 to November 2010. 

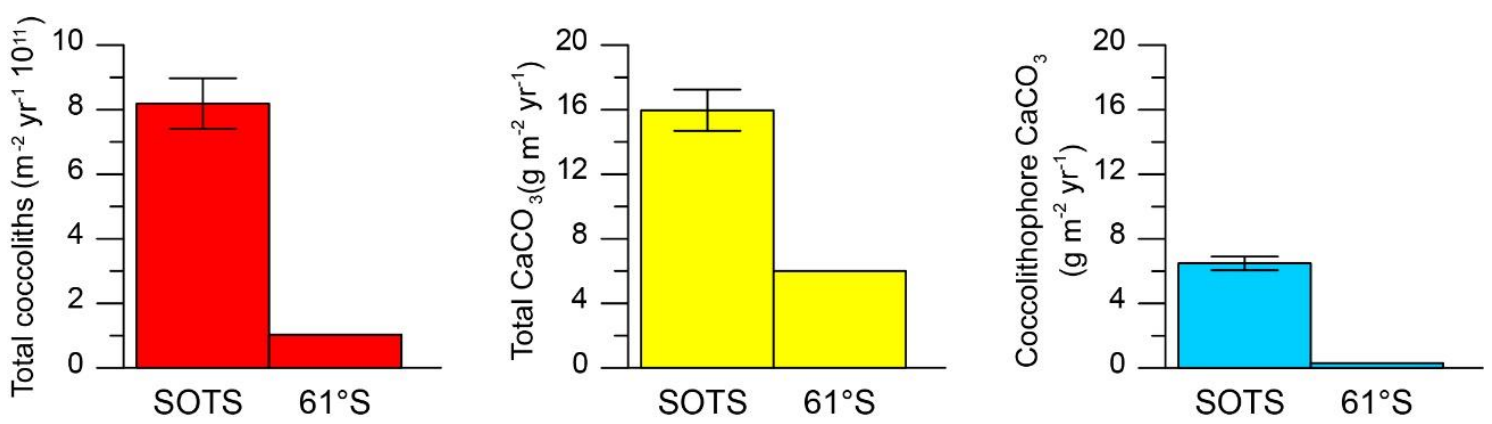

Supplement Figure 2. Annual coccolith, total $\mathrm{CaCO}_{3}$ and coccolithophore $\mathrm{CaCO}_{3}$ fluxes for the $<1 \mathrm{~mm}$ particulate fraction for the SOTS (average for three depths and standard deviation) and $61^{\circ} \mathrm{S}$ sites (Rigual Hernández et al., 2018).

\section{References}

Rigual Hernández, A.S., Flores, J.A., Sierro, F.J., Fuertes, M.A., Cros, L., Trull, T.W., 2018. Coccolithophore populations and their contribution to carbonate export during an annual cycle in the Australian sector of the Antarctic Zone. Biogeosciences 2017, 1-40. 